\title{
INDUSTRIAL DEVELOPMENT AND RACE IN THE NONMETROPOLITAN SOUTH
}

\author{
JAMES L. WALKER*
}

During the 1960's an unprecedented effort was made by the federal government to promote economic development in depressed areas of the nation. Most of this effort was focused on the nonmetropolitan South, where the high rates of poverty, underemployment, and outmigration (especially of blacks to the major metropolitan ghettoes) has been seen as a national problem. ${ }^{1}$ Partially as a result of these federal investments in the economic and social overhead capital of rural communities, the nonmetropolitan South experienced considerable expansion in nonagricultural employment during the 1960-1970 decade. This was especially evident with manufacturing, the growth rate of which was more rapid in nonmetropolitan than metropolitan areas of the South. ${ }^{2}$

While this federally subsidized rural renaissance has had considerable impact upon whites, there is increasing evidence that blacks have not shared equitably in the employment growth and the resultant reductions in poverty, underemployment, and outmigration. The extent of this problem is suggested by observing that while the employment expansion of the 1960's resulted in a major decline in the extent of net outmigration from the nonmetropolitan South, this decline was brought about almost entirely by a drop in the net outmovement of whites. Their net outmigration during this period almost ceased, declining from 2.7 million in the 1950's to .1 million in the 1960's. In sharp contrast, the amount of net outmigration of nonmetropolitan blacks was practically unchanged, declining only from 1.6 million in the 1950 's to 1.3 million in the $1960{ }^{\prime}$ s. $^{3}$

A significant part of the failure of blacks to share equitably in the economic gains can be explained by the tendency for employment growth within the nonmetropolitan South to locate outside of heavily black areas. Even a casual analysis of the location of population and total employment growth in relation to the location of the black population in the nonmetropolitan South reveals this fact. Most of the nonmetropolitan delta counties in Arkansas, Louisiana, and Mississip-

*The author is Associate Professor of Economics and Director of the Bureau of Business and Economic Research, University of Nevada-Reno. Acknowledgment is extended to Niles Hansen, Ray Marshall, and G. Donald Jud and an anonimous referee for their critical comments and helpful suggestions. 
pi that experienced population and employment decline were counties with relatively high proportions of blacks. Similarly, the highly black counties in Alabama, Georgia, and South Carolina were prone to decline. It was the relatively white areas of northwest Arkansas, northeast Mississippi, northern parts of Alabama, Georgia, and South Carolina, and the coastal areas of Louisiana, Mississippi, and South Carolina that largely experienced growth. Niles Hansen, in a recent study of nonmetropolitan counties that experienced population decline in the 1950's but population growth in the 1960's, found that these new growth areas all had one thing in common-they all were areas with predominantly white populations. ${ }^{4}$

The purpose of this study is to analyze this phenomenon, i.e., the extent to which it has been happening and some of the more important explanatory factors. The analysis is based primarily upon 1960 and 1970 census data for a sample of 244 nonmetropolitan counties in six Southern states (Alabama, Arkansas, Georgia, Louisiana, Mississippi, and South Carolina). ${ }^{5}$

\section{NONAGRICULTURAL EMPLOYMENT}

The negative relationship between employment growth and black population concentrations also applies to changes in nonagricultural employment. Within the study's sample of nonmetropolitan counties this can be seen with the assistance of a simple regression model which relates per capita change ${ }^{6}$ in nonagricultural employment, 1960-1970, $(\triangle \mathrm{NA})$ to proportion of the county's population that was black in 1960 (B).

$$
\begin{aligned}
& \Delta \mathrm{NA}=.101-.092 \mathrm{~B}^{* *} \\
& (-.354)
\end{aligned}
$$

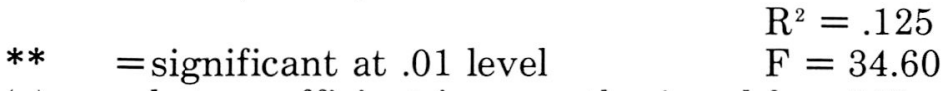

$$
\begin{aligned}
& \text { ( ) =beta coefficient in parenthesis d.f. }=242
\end{aligned}
$$

While the $R^{2}$ is relatively low, the negative regression coefficient is statistically significant and indicates that a 10-point increase in the percentage black was on the average associated with a decline of .009 in the county's per capita change in nonagricultural employment. Alternately, the beta or standardized regression coefficient shows that at the mean, a one standard deviation increase in B was associated with over a third standard deviation decline in $\triangle \mathrm{NA}$.

Since the focus of economic development programs is primarily on the location of new nonagricultural jobs paying above subsistence wages, it may be more meaningful to look at the changes in nonagricultural minus personal service employment, or the modern sector, where wages are generally much higher than in either agriculture or personal services. Doing this with the following regression, where per capita changes in modern sector employment, 
1960-1970 ( $\Delta \mathrm{MS})$, is the dependent variable, we see that the results are very similar to the previous model.

$$
\begin{array}{ccc}
\Delta \mathrm{MS} & =.107-.088 \mathrm{~B} * * & \\
& & \mathrm{R}^{2}=.130 \\
* * & =\text { significant at .01 level } & \mathrm{F}=36.22 \\
() \quad=\text { beta coefficient in parenthesis } & \text { d.f. }=242
\end{array}
$$

Again, while the $\mathrm{R}^{2}$ is fairly low, the negative regression coefficient is clearly statistically significant. Further, the coefficient indicates that a 10-point increase in the proportion black was associated with .0088 less per capital growth in modern sector employment. The economic importance of this is seen by observing that this implies that there would be some 1,312 fewer new modern sector jobs for a heavily black county $(70$ percent black) as compared to a predominantly white county (20 percent black). With county populations for the sample having an average of only 29,820 persons in 1960, 1,312 fewer new modern sector jobs over the decade could spell the difference between continued stagnation and underemployment or growth and improving employment opportunities.

While the simple negative relationship reveals the important fact that modern sector growth was occurring less in the heavily black areas, and thus bypassing some of the poorest areas in the nonmetropolitan South, it does not necessarily follow that employers were discriminating against black areas for reasons of race in their employment location decisions. To get at this question, it would be necessary to first control for some of the more important area characteristics that employers might consider in trying to find an economically suitable location for expansion. If the partial regression coefficient on proportion black was still significantly negative, then the hypothesis of current racial discrimination would be supported. In order to analyze this question, a multiple regression model was estimated that included county variables representing the degree of urbanization, size of the government sector, federal expenditures on economic development activities, skill levels of the labor force, excess supplies of unemployed labor, and wage levels. This yielded the following results:

$$
\begin{aligned}
& \Delta \mathrm{MS}=.182+.126 \mathrm{URB}^{\mathrm{c} * *}-.049 \mathrm{URB}^{* *} \\
& \text { (.268) } \quad(-.238) \\
& +.155 \mathrm{GOV}^{*}+.00002 \mathrm{EOC}^{* *}+.00005 \mathrm{IOP} * * \\
& \begin{array}{lll}
(.073) & (.156)
\end{array} \\
& -.278 \mathrm{UN}^{* *}+.041 \mathrm{WR}^{* *}-.035 \mathrm{~B}^{*} \\
& \begin{array}{lll}
(-.285) \quad(.151) \quad(-.144) & 0
\end{array} \\
& \left(\mathrm{R}^{2}=0.37, \quad \mathrm{~F}=17.15, \quad \text { d.f. }=235\right)
\end{aligned}
$$




\section{Where}

$*$ = significant at the .05 level

$* *=$ Significant at the .01 level

$($ ) = beta coefficients in parentheses

$\Delta \mathrm{MS}=$ per capita change in modern sector employment, 1960-1970

$\mathrm{URB}^{\mathrm{c}}=$ urban influence of outcommuting to urbanized areas, 1960. (This is a dummy variable, coded 1 if 10 percent or more of the labor force commuted to another county with 25,000 or more urban population or 10,000 or more nonfarm jobs, 0 otherwise ${ }^{7}$ )

$\mathrm{URB}=$ urban population as a proportion of total population, 1960

$\mathrm{GOV}=$ government employment as a proportion of total employment, 1960

$\mathrm{EOC}=$ per capita economic overhead capital outlays by the federal government, 1967-1969. (This is intended to be a proxy for expenditure levels for the whole 1960-1970 period. The 1967-1969 data were the only data available. ${ }^{8}$ )

IOP = index of occupational position for nonfarm employment. (The index of occupational position is computed for each county as follows:

$$
\sum_{\mathrm{i}=1}^{9} \mathrm{P}_{\mathrm{i}} \mathrm{Y}_{\mathrm{i}}
$$

where $P_{i}=$ proportion of a county's male employment in occupation $\mathrm{i}$ and $\mathrm{Y}_{\mathrm{i}}=1969$ U.S. median earnings of males employed in occupation i.)

$\mathrm{UN}=$ males who were unemployed or noninstitutionalized nonparticipations as a proportion of all noninstitutionalized males, 14 to 64 years old, 1960

$\mathrm{WR}=$ wage rate proxy, estimated by deflating median family income, 1960, by IOP

$\mathrm{B}=$ black population as a proportion of total population, 1960 .

After having controlled for these more important area characteristics, the negative relationship with proportion black remained. This result supports the hypothesis of current discrimination in the location of employment expansion. While it is not discernible from these results whether the discrimination was resulting primarily from employer prejudices or from the guiding hand of local, state, and federal development agencies, it is apparent that current discrimination in the location of employment growth should be a concern of agencies dedicated to the development of equal opportunities in the nonmetropolitan South.

Even though the hypothesis that current discrimination adversely affects the location of modern sector growth was confirmed, a much more important part of the explanation of why growth is avoiding black areas involves differentials in labor force skill levels between areas. Thomas Till has hypothesized that the skill level of the labor 
force, or labor quality, is a major factor in accounting for growth disparities among nonmetropolitan areas. ${ }^{9}$

One way to measure the relative labor quality by county is through an overall measure of the occupational level of the labor force, the index of occupational position (IOP). The index approximates the money value of a county's nonagricultural occupational distribution. Using the IOP as a proxy for skill level, the above results strongly support the above hypothesis. In fact, based on the ranking of beta coefficients, it is the model's most powerful explanatory variable. The importance of this variable becomes even more pronounced when it is observed that there is a significant negative relationship between the IOP and proportion black. (The simple correlation between B and IOP is -.637.) Black areas, with their low occupational skill levels, are at a distinct disadvantage compared with white areas in competing for the location of employment expansion.

For example, a typical black county with an IOP of $\$ 1,000$ less than a white county could expect some 1,491 fewer new modern sector jobs over the decade as a result of the disparity in skill occupational levels. To the extent that the 1960 skill occupational disparities were created by past discrimination in the labor market, in the provision for human resource development, and in the location of higher skill occupational level employment, the regression coefficient is showing the powerful impact of past discrimination on current employment location patterns. If equal opportunity is a goal of agencies promoting employment expansion in the nonmetropolitan South, then the impact of skill occupational disparities must be explicitly dealt with.

The results in regards to the other independent variables provide further insights into the factors influencing the location of nonmetropolitan growth. The positive regression coefficient on the urban commuting variable $\left(\mathrm{URB}^{\mathrm{c}}\right)$ is consistent with the hypothesis that nonmetropolitan counties with large amounts of commuting to sizable urban centers would experience more rapid employment growth. This is also consistent with the findings of Calvin Beale that Southern nonmetropolitan counties adjacent to metropolitan areas experienced faster population growth than nonadjacent counties. ${ }^{10}$ Hansen explains this phenomenon by arguing that

...today the SMSA is giving way to urban fields which may include whole regions within a two-hour driving radius of the central cities. Increased incomes, leisure, and accessibility have permitted a growing number of persons to avail themselves of opportunities and amenities throughout their urban fields. Thus, many persons who work in SMSA's may reside in nonmetropolitan areas where residential amenities are more agreeable, and many persons who live and work in SMSA's regularly go to nonmetropolitan areas for tourism, recreation, second homes, and retirement. ${ }^{11}$

The second independent variable, URB, was used to test the conven- 
tional hypothesis that because of more efficient functioning of factor and product markets in urban areas, growth would be positively associated with the urbanization of a county. The hypothesis was not supported. This is consistent with the independent findings of Till ${ }^{12}$ and Beale that "contrary to popular impressions of rural areas as economically stagnant and lacking in the ability to attract employment, they have succeeded in recent years in acquiring nonagricultural jobs at a rate higher than that of urban areas." ${ }^{13}$

The next variable, GOV, was used to test the hypothesis that growth would be positively related to areas with relatively large government sectors because of the external economies (more and easier access to services, etc.) that private employers capture from the government sector and because the govenment sector itself has been a growth sector in the past decade. The results are consistent with the hypothesis.

Economists have long argued that government investment in economic overhead capital (including power, communications, transportation, and natural resource development) could be used to accelerate economic development. ${ }^{14}$ Believing that investments in economic overhead capital would induce private investments in directly productive activity, many federal agencies invested heavily in the nonmetropolitan South. The positive coefficient on the EOC variable is consistent with this hypothesis. An alternate hypothesis consistent with the results is that economic development induced the federal investments. ${ }^{15}$ Whether a cause or an effect of growth, it is interesting to note that there is a weak but negative simple correlation between EOC and the proportion of the population black.

It is generally assumed that one of the major attractions of the nonmetropolitan South to would-be employers is the prospect of abundant supplies of cheap labor. Thus, a positive regression coefficient on the UN variable (on the assumption that the male unemployed and the noninstitutionalized nonparticipants satisfactorily represented the presence of surplus labor available for hire) and a negative coefficient on the WR variable (assuming that cheap labor refers to the wage levels of workers after controlling for their skill occupational level) might be expected. The empirical results are contrary to the expectations for both variables. However, the negative regression coefficient on UN is consistent with the regression results of Till. ${ }^{16}$ Very likely, the unemployed and noninstitutionalized nonparticipating males are not the prime target group for employment with new employers, who are characterized by Ray Marshall as tending "to 'cream' by hiring the youngest and best educated people in rural areas." ${ }^{17}$ And the positive coefficient on WR could be explained by the possibility that WR is a proxy for skill level within occupations, on the assumption that wages and incomes are correlated with skill levels. If this is correct, then black areas are disadvantaged not only by their low occupational structures, but also by their low skill levels within occupations, and this is further evidence that past discrimination plays a role in current employment problems for blacks. At any rate, the results on these two 
variables support the observation by Vernon Briggs that "the South needs educated and skilled workers to meet the needs of its expanding private businesses and burgeoning defense industries. Its one time asset-cheap and unskilled labor-has become an albatross." ${ }^{18}$

\section{MANUFACTURING EMPLOYMENT}

Since manufacturing is the major sector with which economic developers have concerned themselves, and since it is a very important economic base activity, further analysis of the location of manufacturing employment is certainly in order.

In several recent studies it has been observed that manufacturing employment has generally not been expanding in the heavily black areas of the nonmetropolitan South. For example, Hansen found:

The Southern turnaround counties that have been the primary beneficiaries of industrial decentralization are overwhelmingly white in racial composition. The largest block of Turnaround-Reversal counties in the nation is that in the Ozarks. The remarkable industrial growth taking place in Mississippi is concentrated in a few counties in the northeastern part of the state; similar expansion is occurring in northern Alabama. Some of the most impressive manufacturing growth in the nation is in Tennessee (apart from some southwestern counties), northern Georgia and the Piedmont. These areas have one element of homogeneity that is even more striking than their industrial expansion: despite the fact that they are Southern they have proportionally fewer blacks than the nation as a whole. ${ }^{19}$

Similarly, Rich Lonsdale found a strong negative relationship between industrial growth and percent of the population Negro in a sample of rural counties in North Carolina, Georgia, and Mississippi. Lonsdale explains this phenomenon by arguing that "in general, rural Negroes are poorly educated and often need 'literacy training' as a prerequisite to job training. Related to this is a fear on management's part that Federal guidelines on fair employment practices will call for an employment mix consistent with the racial mix of the area where the plant is located". ${ }^{20}$ In addition, Hansen argues that

Many employers believe that blacks are less productive and more prone toward organization by unions... Whatever superficial merit these arguments may have, it cannot be denied that racial discrimination plays a part in the failure of firms to locate in "black" areas. However, the issue is not solely one of overt racism on the part of those who decide where firms will locate. Past and present discrimination against blacks in the provision of health, education and other human resource investments has created a labor force that may really be relatively less productive. ${ }^{21}$ 
Thus, in a statistical analysis of the nonmetropolitan South, one would expect to find a negative relationship between manufacturing growth and the proportion of the population black (both before and after control for other variables) and positive relationships between manufacturing growth and various measures of labor quality, including the skill occupational level and the educational level of the labor force. The results of simple and multiple regression analyses only partially support the above expectations (see Table 1).

The significant negative functional relationship between change in manufacturing employment and proportion of the population black (see the first regression) is consistent with the findings of both Hansen and Lonsdale. However, the extremely low $\mathrm{R}^{2}$ and the small beta coefficient reveal that the relationship is much weaker than was the case for changes in modern sector employment. Further, the rather small regression coefficient suggests that we might expect to find 253 fewer new manufacturing jobs in a typical 70 percent black county as compared to a 20 percent black county.

TABLE 1

THE LOCATION OF MANUFACTURING EMPLOYMENT GROWTH: REGRESSION ANALYSES

Dependent Variables

\begin{tabular}{|c|c|c|c|c|c|c|}
\hline \multirow{2}{*}{$\begin{array}{c}\text { Independent } \\
\text { Variables }\end{array}$} & \multicolumn{2}{|c|}{$\Delta$ Manufacturing } & \multicolumn{2}{|c|}{$\Delta$ Durable } & \multicolumn{2}{|c|}{$\Delta$ Nondurable } \\
\hline & $\begin{array}{l}\text { (1) Simple } \\
\text { Regression }\end{array}$ & $\begin{array}{l}\text { (2) Multible } \\
\text { Regression }\end{array}$ & $\begin{array}{l}\text { (3) Simple } \\
\text { Regression }\end{array}$ & $\begin{array}{l}\text { (4) Multiple } \\
\text { Regression }\end{array}$ & $\begin{array}{l}\text { (5) Simple } \\
\text { Regression }\end{array}$ & $\begin{array}{l}\text { (6) Multiple } \\
\text { Regression }\end{array}$ \\
\hline Intercept & .033 & -.092 & .020 & -.099 & .013 & .020 \\
\hline $\mathrm{URB}^{\mathrm{c}}$ & & $\begin{array}{l}.010^{* *} \\
(.164)\end{array}$ & & + & & $\begin{array}{l}.007 * * \\
(.177)\end{array}$ \\
\hline URB & & -.035 & & $-.012 * *$ & & $-.021 * *$ \\
\hline GOV & & $(-.313)$ & & $(-.154)$ & & $(-.246)$ \\
\hline GOV & & - & & $\begin{array}{c}-.109^{*} \\
(-.137)\end{array}$ & & + \\
\hline MFG & & $\begin{array}{l}.038 * * \\
(.200)\end{array}$ & & $\begin{array}{l}.011 \\
(.080)\end{array}$ & & $\begin{array}{l}.026 * * \\
(.183)\end{array}$ \\
\hline $\mathrm{EOC}$ & & + & & + & & - \\
\hline IOP & & $\begin{array}{l}.00002^{* *} \\
(.303)\end{array}$ & & $\begin{array}{l}.00002^{* *} \\
(.392)\end{array}$ & & + \\
\hline ED & & - & & + & & - \\
\hline UN & & $\begin{array}{l}-.089 * * \\
(-.169)\end{array}$ & & $\begin{array}{l}-.039^{*} \\
(-.105)\end{array}$ & & $\begin{array}{l}(-.040) \\
(-.099)\end{array}$ \\
\hline WR & & - & & + & & - \\
\hline B & $\begin{array}{l}-.017^{*} \\
(-.130)\end{array}$ & - & $\begin{array}{l}-.020 * * \\
(-.211)\end{array}$ & - & + & - \\
\hline \multicolumn{7}{|c|}{ Overall Statistics: } \\
\hline $\mathrm{R}^{2}$ & .017 & .179 & .045 & .169 & .000 & .138 \\
\hline $\mathrm{F}$ & 4.14 & 10.35 & 11.30 & 9.65 & .24 & 9.57 \\
\hline d.f & 242 & 238 & 242 & 238 & 242 & 239 \\
\hline
\end{tabular}




$$
\begin{aligned}
& \text { Where } \\
& *=\text { significant at the } .05 \text { level } \\
& * *=\text { siginificant at the } .01 \text { level } \\
& -,+=\text { The }+ \text { or }- \text { signs without regression coefficients }
\end{aligned}
$$

All other variables are explained on p. 36.

Using the logic of economic base analysis, which assumes that basic employment growth can be used to "explain" total employment growth, it is apparent that the "misallocations" of manufacturing employment growth can only partially explain the much larger differentials in total employment growth.

The location tendencies of three other economic base activities deserve mention. First, agriculture was the major declining sector in the nonmetropolitan South and the heavily black areas were generally much more involved in agriculture (the simple correlation between $B$ and agriculture as a proportion of total employment, 1960, was + .626). The location of the other two activities, state colleges and recreation-retirement, was found by Beale to be associated with above average population growth rates for the nonmetropolitan South between 1960 and $1970 .{ }^{22}$ While no direct evidence is available, the presumption is that these were located mainly in predominantly white areas. These findings suggest that concern over the "misallocation" of economic base activity growth should not be limited to manufacturing but should include other base sectors that are also largely bypassing the heavily black areas.

To explore the reasons behind the location patterns of manufacturing growth, a multiple regression model (see Table 1, regression 2) was estimated using many of the same independent variables as used in the earlier modern sector model. While all the independent variables listed in Table 1 were available for entry in the stepwise multiple regression model, only five variables were significant at the .10 level or better and thus allowed to enter. Manufacturing as a proportion of total employment, 1960 (MFG), was used as a control for the initial size of the manufacturing sector and, as expected, had a positive coefficient. Since the remaining four significant independent variables $\left(\mathrm{URB}^{\mathrm{c}}\right.$, URB, IOP, and UN) provided results which were generally the same as in the earlier modern sector model, further discussion of these variables will be limited to noting that IOP, representing the skill oc- 
cupational level of the labor force, again was a very important variable. The strong relationship suggests the powerful impact of past discrimination on the current location decisions of manufacturers.

An additional labor quality variable, the education level of the labor force (ED), was tried, but it was not significant enough to enter the stepwise regression model. This is consistent with the results of Till, who found that median years of schooling and local government educational expenditures were insignificant independent variables in a regression model explaining manufacturing growth rates in the nonmetropolitan South. ${ }^{23}$ These results conform to the general picture of manufacturers' primarily using previous occupational skill levels, rather than years of schooling, as the major labor quality variable of relevance. This suggests that manpower programs involving job skill development (vocational education, institutional and on-the-job training programs, public employment, etc.) may be more useful than general education in overcoming the unattractiveness of many of the black counties to potential manufacturing employers.

Finally, after having controlled for the above significant independent variables, there was found to be no significant relationship between $\triangle \mathrm{MFG}$ and $\mathrm{B}$. Thus, the hypothesis of current discrimination in the location of manufacturing growth was not supported. It is possible that the significance of this variable was affected by the nature of the study's sample of counties (see footnote 5). However, Till, using a random sample of counties in ten states of the nonmetropolitan South, also found no significant relationship between manufacturing employment growth rates and percent of the population black. ${ }^{24}$ It is likely that the main explanation for the "misallocation" of manufacturing growth lies with other area characteristics relevant to industrial locators, many of which undoubtedly were affected by past discrimination. Therefore, it appears that efforts to further direct industrial expansion to heavily black areas should be primarily focused on activities such as improving the quality of the labor force through manpower programs rather than on antidiscrimination programs directed at industrial locators.

Several interesting results were found by disaggregating the manufacturing sector into durable and nondurable goods (see Table 1, equations 3-6). First, while change in durable goods manufacturing employment was negatively related to the proportion of the population black, the relationship was insignificant but positive for changes in nondurable goods manufacturing. Thus, it appears that black areas are getting their "fair share" of the lower wage nondurable goods sector while at the same time failing to share equally in the growth of the higher wage durable goods sector. ${ }^{25}$ Further disaggregation would probably show an even stronger tendency for high-wage industries to be repelled, while low-wage industries were attracted to the depressed black population concentrations. The primary explanation behind this is not found in current discrimination in industrial location but rather in differences in the demand for labor quality. High-wage industries, 
generally being demanders of higher skills in their work forces, are strongly repelled by the low skill occupational levels of the labor forces characteristic of black areas. In contrast, the low-wage industries are not deterred by low skill occupation levels. Thus, again is seen the role that past discrimination plays in depriving black areas of the fruits of growth.

\section{POLICY IMPLICATIONS}

The primary policy implications of this analysis are that while concern to prevent current racial discrimination by those responsible for the location of growth should not be discouraged, the main focus of a program to encourage a more equal distribution of growth should be on overcoming the labor quality problem. While general education undoubtedly has a role to play, manpower programs that improve the skill and occuaptional levels of the labor force may be more useful for attracting more and better employment growth.

The results further suggest the possible role that could be played by Community Development Corporations (CDC's) in areas that have failed to attract any significant growth in the past and hence remain disadvantaged in attracting industry in the future. CDC's could be instrumental in attracting the initial industries that could raise occupational and skill levels of the local labor force. This in turn could serve as the catalyst for further development by providing a demonstration that skilled labor was available and/or readily developed through training and that industrial expansion was not only feasible, but also profitable. Furthermore, CDC's by encouraging and becoming involved in the development of commerce, housing, education, and training programs, could be instrumental in creating an overall climate favorable for growth. ${ }^{26}$

However, the likely role of CDC's will probably be small relative to the role played by federal, state, and regional programs aimed at encouraging expansions of major corporations in depressed areas and by manpower programs that encourage occupational upgrading of the poor. Furthermore, there are undoubtedly many heavily black areas that are better suited for agriculture rather than industrial development. Attempting to promote growth through any means in these areas may be less efficient than educational and skill development programs coupled with relocation programs that encourage mobility to viable growth areas. If the real concern is with the people in poverty rather than with the places, this policy alternative should receive serious consideration when an area appears to be unable to be developed without massive subsidies. ${ }^{27}$

\section{FOOTNOTES}

'John F. Kain and Joseph J. Persky, "The North's Stake in Southern Rural Poverty," in Rural Poverty in the United States, issued by the President's Advisory Commission on Rural Poverty (Washington, D.C.: Government Printing Office, May, 1968).
2 Thomas E. Till, "Rural Industrialization and Southern Rural Poverty in the 1960's: Patterns of Labor Demand in Southern Nonmetropolitan Labor Markets and Their Impact on Poverty" (unpublished Ph.D. dissertation, University of Texas, 1972). Also, see Claude C. Haren, "Rural Industrial 
Growth in the 1960's," American Journal of Agricultural Economics, Vol. 52, No. 3 (August, 1970), pp. 431-437; and Clark Edwards, Robert Coltrane, and Stan Saberkow, Regional Variations in Economic Growth and Development with Emphasis on Rural Areas, Agricultural Economics Report No. 205 (Washington, D.C.: Economic Research Service, U.S. Department of Agriculture, May, 1971), pp. 1-185.

${ }^{3}$ Calvin L. Beale, "The Nature and Significance of Recent Population Trends in the South, with Particular Reference to Nonmetropolitan Areas," paper prepared for The Poverty Dimensions of Rural-to-Urban Migration (Washington, D.C.: Office of Economic Opportunity and U.S. Department of Agriculture, March, 1973), p. 6.

+ Niles Hansen, "Population Turnaround in Nonmetropolitan Regions: Its Implications for Manpower and Regional Policies," Final Report to the Office of Research and Development, Manpower Administration, U.S. Department of Labor (Austin: Center for Economic Development, University of Texas, 1973)

${ }^{5}$ The six state sample of counties included all those observations which were nonmetropolitan as of the 1970 census and had at least 5,000 black population in 1960. Unless otherwise noted, all the county data used in constructing variables for the following regression analyses came from U.S. Bureau of the Census, Census of the Population, 1960 and 1970, General Social and Economic Characteristics, PC(1)-C2, C5, C12, C20, C26, and C42 (Washington, D.C.: Government Printing Office, 1963 and 1972).

${ }^{6}$ Per capita change refers throughout the text to the 1960-1970 change in employment deflated by 1960 county population.

${ }^{7}$ Derived from Economic Research Service, U.S. Department of Agriculture, Characteristics of U.S. Rural Areas with Noncommuting Population (Washington, D.C.: Government Printing Office, 1972), pp. 3-4 and appendix.

${ }^{8}$ Derived from U.S. Office of Economic Opportunity, tapes "Federal Outlays in Fiscal Year 1968, 1969, and 1970" (Washington, D.C.: Office of Economic Opportunity, 1969, 1970, and 1971).

${ }^{9}$ Till, p. 204.

${ }^{10}$ Beale, p. 31.

"Hansen, chapter 12, p. 3. For a full development of this hypothesis, see John Friedman and John Miller, "The Urban Field," Journal of the American Institute of Planners, Vol. 31 , No. 4 (November, 1965), pp. 312-319.

${ }^{12}$ Till, p. 172.

${ }^{13}$ Beale, p. 43.
14 Ragnar Nurske, Problems of Capital Formation in Underdeveloped Countries (New York: Oxford University Press, 1967), pp. 152-154.

15 See Albert O. Hirschman, The Strategy of Economic Development (New Haven, Yale University Press, 1958), especially pp. 86-87, for the general development of this hypothesis.

${ }^{16}$ Till, p. 176.

${ }^{17}$ Ray Marshall, "Policy and Program Issues in Rural Manpower Development," discussion paper (Austin: Center for the Study of Human Resources, University of Texas, mimeograph, December, 1971), p. 21.

18 Vernon M. Briggs, Jr., "Manpower Programs and Regional Development," Monthly Labor Review, Vol. 91, No. 3 (March, 1968), p. 60.

${ }^{19}$ Hansen, Chapter 12, p. 3.

${ }^{20}$ Rich E. Lonsdale, "Deterrents to Industrial Location in the Rural South," Research Previews, Vol. 16 (April, 1969), pp. $3-4$.

${ }^{21}$ Hansen, Chapter 12, p. 3.

${ }^{22}$ Beale, pp. 34-46.

${ }^{23}$ Till, pp. 171-180. The education variable was also insignificant when inserted into the $\triangle \mathrm{MS}$ model.

${ }^{24}$ Ibid.

${ }^{25}$ The national average weekly earnings of production workers in 1970 was $\$ 143.47$ in durable goods manufacturing and $\$ 120.43$ in nondurable goods manufacturing, according to the U.S. Bureau of Labor Statistics, Employment and Earnings United States, 1909-71, Bulletin 1312-8 (Washington, D.C.: Government Printing Office, 1972), p. xv.

${ }^{26}$ The few evaluations that have been made of CDC's suggest that they have been reasonably successful in developing enterprises that at least have the potential to be profitable and to have an overall impact on minority communities. For example, see Jerry Cromwell and Peter Merrill, "Minority Business Performance and the Community Development Corporation," Journal of Black Political Economy (Spring, 1973), pp. 65-81; Barry A. Stein, "How Successful Are CDC's? An Interim Response," Journal of Black Political Economy (Spring, 1973), pp. 84-99; and Ford Foundation, "Community Development Corporations: A Strategy for Depressed Urban and Rural Areas," a policy paper (New York: Ford Foundation, May, 1973), pp. 1-30.

${ }^{27}$ For a lucid elaboration of this point of view, see Niles $M$. Hansen, Rural Poverty and the Urban Crisis (Bloomington, Indiana: Indiana University Press, 1970). 